\title{
An Experience of Science Theatre to Introduce Earth Interior and Natural Hazards to Children
}

\author{
Gemma Musacchio ${ }^{1}$, Tiziana Lanza ${ }^{1} \&$ Giuliana D’Addezio ${ }^{1}$ \\ ${ }^{1}$ Istituto Nazionale di Geofisica e Vulcanologia,Via di Vigna Murata, Italy \\ Correspondence: Gemma Musacchio, Istituto Nazionale di Geofisica e Vulcanologia, Via di Vigna Murata, 605, \\ Italy. Tel: 39-02-2369-9255. E-mail: gemma.musacchio@ingv.it
}

Received: December 23, 2014

Accepted: September 29, $2015 \quad$ Online Published: November 9, 2015

doi:10.5539/jel.v4n4p80

URL: http://dx.doi.org/10.5539/jel.v4n4p80

\begin{abstract}
The present paper describes an experience of science theatre addressed to children of primary and secondary school, with the main purpose of making them acquainted with a topic, the interior of the Earth, largely underestimated in compulsory school curricula worldwide. A not less important task was to encourage a positive attitude towards natural hazards that are here presented as an expression of our planet vitality. We conducted the experience with the help of a theatrical company specialized in shows for children, trying to merge scientific accuracy, entertainment and ethical issues. Several performances have been reiterated in different context, giving us the opportunity of conducting a preliminary survey with a public of different ages, skills and expectations. Results suggest that science theatre, while relying on creativity and emotional learning has the potential to raise children interest on the process of making science, on natural phenomena and may trigger a positive attitude on natural disasters reduction best practices.
\end{abstract}

Keywords: science outreach, geoscience education, seismic hazard, volcanic hazard

\section{Introduction}

The strong attention of general public towards scientific knowledge has recently boosted science communication activities (Hodder, 2001; Carpineti, 2006; Anthoine et al., 2010; Hunstad et al., 2013; D'Addezio et al., 2014; Musacchio et al., 2015). Whatever the format, public events provide an interface between science and society playing an important role in raising awareness and stimulating debate on important contemporary issues. One central point is the need for earth science to be taught to young people. Early acquaintance with earth science is not only necessary for science's workforce requirements, but is also essential for science literacy. Issues surrounding public scientific literacy have never been more critical. The need for understanding the ways in which dynamic Earth systems interact with implications for personal decisions, public infrastructure, and global public policies had raised severely over recent decades. Essential to the success of this challenge will be the extent to which all students are given the opportunity to study earth science as a fundamental part of their education. Moreover, through outreach activities designed to be interesting and engaging, student finds-often unexpectedly-that they enjoy the subject and want to become further engaged; they essentially "stumble" into geoscience generating broad awareness and interest.

Universities and scientific institutions outreach activities often attract people of all ages. Portable models, cooperative learning strategies, science box tools, and science games help to highlight specific aspects of natural phenomena. Nevertheless, they actually rely more on the cognitive aspect of learning neglecting both creativity and imagination.

Creativity is crucial to science as it activates problem finding and visualization through the ability of imagining things in the mind's eye. Regression is also part of the process since creativity stimulates thinking playfully like a child. It leads to new ideas and to the logical thinking (Rule, 2005). Studies highlighted that creative potential grows with creative accomplishments, and then involving students in creative school activities will increase creative achievements and will have an impact on future scientists (Taft \& Gilchrist, 1971; Davis, 1975).

Theatre has the potential to reduce the gap between the cognitive and the creative learning passing from the idea of a strictly data-driven science to an idea of science driven by creativity and imagination. In creating suspense, it captures and holds attention while encouraging audience to be curious about the world, peering through the 
lens of science. It might even encourage the audience to grapple with difficult issues and concepts. History reveals that society has benefited from the successful symbiosis that science and theatre have shared for at least two millennia (DeMetz, 2007). In recent years, acting companies and/or scientists have used theatre to popularize physics (Carpineti et al., 2005, 2006, http://www.pa.msu.edu/sci_theatre/) bio- and medical science (http://www.theatrescience.org.uk/ee/), chemistry (http://www.pa.msu.edu/sci_theatre). Since interest or dislike in science seems to start before high school (Carpineti et al., 2005; Musacchio et al., 2012; and reference therein), science theatre performances can also represent a good device for motivating primary and secondary school students to learn science.

In this study we describe how we used theatre to stimulate children interest on the impact of science in everyday life with a particular attention to natural hazards. We worked with an acting company to put on scene "When the sky flashed red" (Rota, 2012), the story of an imaginary journey to the interior of the Earth, seen as an opportunity for primary and secondary school children to approach in a non conventional way a subject that usually is not even included in most compulsory school curricula worldwide (Bernhardsdóttir et al., 2012; Komac et al., 2013; Musacchio et al., 2015). Scientists and artists both challenged their mutual expertise, attempting new ways to install enthusiasm and appreciation for science, while triggering fundamental changes in society. The Company, Teatro del Sole (www.teatrodelsole.org), is specialized in plots and scenery for children being already engaged in science theatre. They wrote the script while scientists involved in science communication strategies for schoolmates (Musacchio et al., 2012; Lanza et al., 2014) revised it and took especially care of the scientific content.

\section{The Script and the Performance: A Bridge between Science and Imagination}

With the intent of stimulating children curiosity on a severely underestimated topic of formal education and having in mind that it is impossible to visualize the interior of the Earth on the stage, we build a script relying mainly on the children imagination. The journey through Earth interior is also a passage through science knowledge, on a subject where knowledge is still nowadays achieved assembling one-by-one and step-by-step indirect proofs. The journey is also a chance to describe scientists' life, thoughts, attitudes, and make children think over the potential that science has in daily life.

In a magic night when a forecasted aurora borealis turned the sky red, a scientist with two assistants start the most important enterprise of their lives: "A journey to the centre of the Earth" (Figure 1). The playbills of the show is based on a graphic study that strongly refers to the inner of the Earth, as matriosca layers that recall the increasing temperature towards the Core: young explorers and a mystery man seem not to care for journey-related dangers.

The opening scene of the show is inspired to a true aurora borealis, occurred on April 7th 2000 that lighted the entire northern hemisphere down to $46^{\circ}$ of Latitude with an intense red light. Professor Halley, an imaginary relative of Edmund Halley's (1656-1742), thought that the best time to make a journey inside the Earth would be a predicted aurora. His nephew Axel, a scientist lacking the sense of adventure, is happy with a flat, one-dimensional knowledge suggesting that he might have become a scientist just to meet the tradition of his family name. Finally, Aurora, Halley's assistant, embodies the creative, curios scientist stereotype with no fear for the natural world. However, every character is strictly related to the other two. 


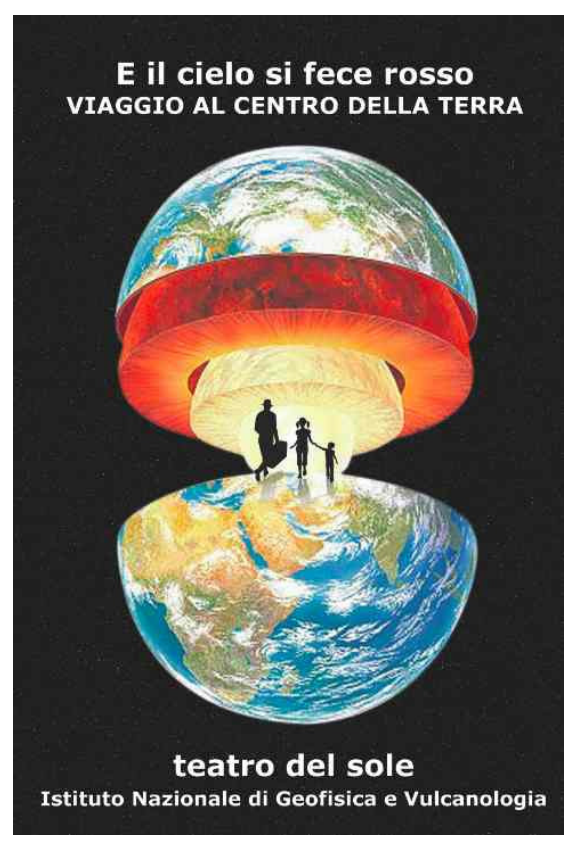

Figure 1. The playbill of the show

The plot relies on imagination, as Halley never shows up on stage. Axel and Aurora talk with him while exploring the Earth interior sharing with the public the adventure of science in-between mantle plumes rising from the core, slabs of cold ocean floor diving back into the Earth, magma chambers that none has ever seen before. Children are encouraged to imagine Halley sliding down the Earth riding magnetic flux lines, while Aurora introduces the Earth Interior showing the link between the outer Core and our life.

The journey starting from a karst cave in the Southern Alps deliberately provoke a misunderstanding as actors pretend to find an ocean just at the bottom of the cave: uncle Halley while was canoeing on a underground karst river hands-on the ocean Thetis rocks now incorporated within the Alpine orogen. The creative strategy gives us the opportunity of discussing Plate Tectonics and Earth interior. As Axel gets more and more involved, uncle Halley discusses the heat transfer from the Core to the bottom of the Lithosphere explaining mantle convection and plumes. Halley started his journey from a karst cave in the Alps and popped out down south Mount Etna giving Aurora the opportunity to explain volcanism. Taken by enthusiasm she recalls that when she was a child she used to build a "special volcano". The music accompanies the acting of the two scientists dreaming to go back to childhood by building a volcano picking up rocks on the stage.

Suddenly, Halley's metallic voice, coming from inside the Earth, announces he has reached the other side of the Earth where rocks failure on the San Andreas Fault has caused an earthquake. The dialogue then focuses on earthquakes, seismic and volcanic hazard while emphasizing that risk might be mitigated by preparedness strategies. Finally, Axel's fear is relieved while Aurora envisages an Earth without earthquakes and volcanoes: the outer Core will finally solidify, children will no longer imagine to ride a convective cell exploring the whole Mantle, and the Earth will stop living from inside. The conclusion of the journey in a poetic and melancholic mood engages audience emotionally inviting children to think over the interior of the Earth as the origin of the natural and beautiful landscapes they are used to admire. They are encouraged to think that if earthquakes and volcanoes belong to the life of our Planet we have the duty to learn how to be prepared.

Preparedness as a disaster prevention strategy is a crucial point where formal education is unsatisfactory worldwide (Tanner, 2010; Komac, 2013; Musacchio et al., 2015) and on which science theatre may promptly intervene.

Recent studies have highlighted that, among all, special courses to educate students on earthquakes and volcanoes hazards and risks are neither provided nor compulsory even in land threatened by natural phenomena (Bernhardsdottir et al., 2012; Musacchio et al., 2015). Local awareness of seismic hazard can balance the lack of proper education in schools, by informal education (Bernhardsdottir et al., 2015). 

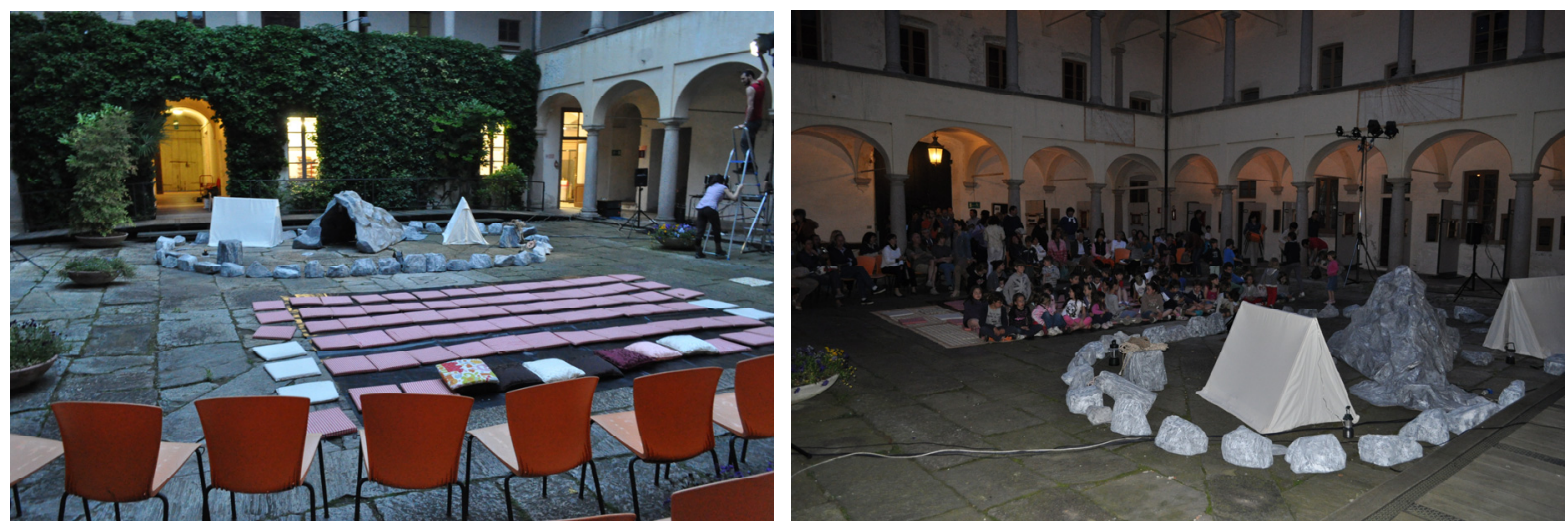

Figure 2. A former convent's cloister was turned into a theatre. a) in the background the stage with an extremely simple set: a cave, two tents and rocks all around. Pillows are seats for children. b) the cloister is about to be filled with people waiting for the beginning of the play

Theatre can be part of the process that relies on informal education. As from experiments performed in developing countries, theatre has the potential to serve as a vehicle for knowledge transfer and also to serve as an agent for change (Walker, 2010). There is a general consensus that the learning process that mostly suite children is emotional learning (Lepper \& Cordova, 1992). Theatre meets it since motivate learning starting from emotions instead of concepts and from fascination instead of just listening.

We deliberately set the stage extremely simple (Figure 2a), including only few objects belonging to the normal equipment of geologists: the safety helmets, tools and dressings they need to enter a karst cave, two tents, since they spend days collecting data, and a model of an entrance to a cave. Actors are scientists working in "the field". In fact, the whole story is acted outdoor, next to the rocks, the main subject of any geoscientist investigation. We deliberately let the audience imagine Earth interior pretending that somebody may describe it to us while taking a journey inside it, a device to emphasize that only indirect analysis (and imagination) supports Earth interior hypotheses. Performances must be far away from recalling classroom lessons (Carpineti et al., 2007; 2011) and science theatre makes this possible: the darkness prevents the audience to take notes, as they usually would do during a lesson. The whole scenic environment, including silence, sounds, lights, and the acting itself embark public in a fantastic journey. A poor scenery has boosted the audience imagination while raising interest on concepts that normally would need a whole set of lessons to be addressed.

In the same vein, we deliberately avoided popularization, using words as "karst", "electromagnetism" and "convective cell" explained by the proper mimic we suggested to actors. We exploited theatre peculiarity of letting the audience struggles a bit, allowing certain principles to remain complicated and elegantly remote rather than making concepts fully intelligible. Also the actors make use of the available theatrical technologies and appeal to poetry mixed with science, thriving on imagination to make theory more interesting. Nevertheless, even if the plot is inspired by Jules Verne's novel, it differs from it in several ways. For instance, our journey does not start diving into a volcano conduit, since in terms of scientific consistency is not reliable. Moreover, such a journey might have suggested that volcanic areas could be suitable for deep borehole drilling, or reinforce a typical misunderstanding by general public that volcanoes dig out magma from the Earth Core. We preferred a karst cave within limestone representing the Pangea sedimentary layering letting imagination meeting cognition.

Finally, even if Science theatre has often been presented in the form of coordinated "hands-on" demonstrations, strongly encouraging interaction with the audience. Carpineti et al. (2005, 2006) (http://www.pa.msu.edu/sci_theatre/; http://www.theatrescience.org.uk/ee/) in our case we found more suitable the self-contained stage show format since the Earth interior appeals to imagination rather than hands-on theatrical show. Our then is a classical one with real actors. 


\section{Identification and Elaboration of the Methodology}

We experienced theatre in a scientific context, and we attempted to set up a methodology that takes into account the target audience and relies on a feedback.

Concerning the audience, we decided to address the plot mainly to children and rely on their potential to spread knowledge and information in a chain-reaction manner involving adults belonging to their surrounding. Children have a valuable and unique ability to conceptualize and analyze risk as their perception is built on their own experience of local disasters, combined with emotions gained from external sources as the media, school curricula and training sessions (Tanner, 2010). Although we decided that the language had to be strictly scientific, we maintained that the plot, the scene and characters had to be set mainly to appeal children, since while feeling empathy towards a character they will easily understand the message.

There is a general consensus that the learning process that mostly suite children is emotional learning (Lepper \& Cordova, 1992). Theatre meets it since motivates learning starting from emotions instead of concepts and from fascination instead of just listening. The set-up of the performance started from the message we wanted to deliver relied on specific strategies concerning the scenery, the language and the format.

We wanted to completely involve them in the story and let them imagine what actually science can still only suppose. Even the scenery has been meant to help in this direction.

We let the scenery extremely simple so the audience would have the chance to fully concentrate on a few basic concepts. Conversely we avoided popularization and choose the use of technical words explained to the audience in a simple and appealing manner.

The feedback was assessed by a pilot survey aimed to investigate to which extent children familiarized with the complexity characterizing the interior of the Earth and expressed within the show. We appointed a semi-structured questionnaire, keeping free only a few questions, focusing on the appreciation, the emotional and cognitive aspects of learning. We explored if, even without visualizing it, children were able to capture, guided by their own imagination, how the Earth evolved driven by its internal forces. Another interesting aspect of the survey was to observe the emotional attitudes of children towards natural hazard as driven by the performance itself. Finally, we also enquired how they think a scientist should behave to make good science

The questionnaires were distributed at the end of performances held within the Genova Science Festival (November 2012) the European Researchers Night (September 2013), the ScienzAperta at INGV (April 2013) and at the International Ceramic Museum (June 2013). The show took place 15 times, during science festivals, open days, schools and museums events, involving more than 3000 people and in different contexts, including places where science usually do not go on scene (i.e., the former monastery), with audiences not necessarily interested or involved a priori on scientific issues (Table 1).

Table 1. List of performances

\begin{tabular}{|c|c|c|c|c|}
\hline Date & Place & Venue & Location & Audience \\
\hline $1 / 11 / 2012$ & Genoa & Science Festival & Teatro della Tosse & 200 mixed public \\
\hline $10 / 11 / 2012$ & Milano & Generic Cultural venue & Public Library & 100 mixed public \\
\hline $19 / 2 / 2013$ & Brescia & Science theatre events & Teatro Santa Giulia & 250 students and teachers \\
\hline 20/2/2013 & Brescia & School & Conference Hall & 300 students and teachers \\
\hline $21 / 2 / 2013$ & Milano & School & Conference Hall & 200 students (6-10 years old) and \\
\hline $22 / 2 / 2013$ & Varese & School & Conference Hall & 150 students (11-13 years old) and \\
\hline \multirow[t]{3}{*}{$19 / 4 / 2013$} & Roma & ScienzAperta & INGV hallway & 140 mixed public \\
\hline & Milano & School & Theatre & 400 students and teachers \\
\hline & Milano & School & Theatre & 400 students and teachers \\
\hline $8 / 6 / 2013$ & Varese & Generic Cultural venue & $\begin{array}{l}\text { International Ceramic } \\
\text { Museum }\end{array}$ & 170 mixed pubblic \\
\hline $27 / 09 / 2013$ & Frascati & $\begin{array}{l}\text { Frascati Scienza: The } \\
\text { European Reserches Night }\end{array}$ & $\begin{array}{l}\text { Theatre Scuderie } \\
\text { Aldobrandini }\end{array}$ & 300 mixed public \\
\hline $\begin{array}{l}13-14 / 10 / 2 \\
01313\end{array}$ & $\begin{array}{l}\text { Bergam } \\
\text { o }\end{array}$ & $\begin{array}{rll}\begin{array}{c}\text { Bergamo } \\
\text { festival) }\end{array} & \text { Scienza } & \text { (Science } \\
\end{array}$ & Civic Theatre & $\begin{array}{l}300 \text { mixed pubblic and } 300 \text { students } \\
\text { and teachers }\end{array}$ \\
\hline
\end{tabular}




\begin{tabular}{lllll}
\hline $12 / 2 / 2015$ & Milano & School & Conference Hall & 200 students $(6-10$ years old) and \\
$26 / 2 / 2015$ & Milano & School & Conference Hall & 200 students $(6-10$ years old) and \\
$19 / 3 / 2015$ & Milano & School & Conference Hall & 200 students $(6-10$ years old) and \\
$22 / 4 / 2015$ & Bergam & School & Conference Hall & 200 students $(6-10$ years old) and \\
\hline
\end{tabular}

Note. The show was performed 15 times and in different context involving people ranging from scholars to general public

It premiered at the Science Festival held in Genoa on October 2012 (www.festivalscienza.it), the biggest event in Europe for disseminating scientific culture, at its 10th edition. The other performances took place at the 2013 European Researchers' night within Frascati Scienza (http://www.frascatiscienza.it) and at the Bergamo science festival (http://www.bergamoscienza.it). We presented the show also at INGV, where tens of children were sitting on the floor, during ScienzAperta 2013 (open doors to science, www.scienzaperta.ingv.it). Every year this venue is a chance to meet the INGV scientists and share with the community the places of science through events, open laboratories, activities for children (D'Addezio et al., 2014). Indeed when the portico of a former convent's cloister now hosting an art museum (the International Museum Ceramic Design: http://www.midec.org/) housed the show in a summer night (Figure 2), the public was not necessarily interested in science, but the impact was extremely positive. Performances in schools are still ongoing.

\section{Discussion}

In total, we collected 280 questionnaires, $65 \%$ of which were compiled by children. Other opinions were collected orally, speaking directly with the adults (parents) and the teachers attending the performance. The surveyed sample is small respect to the total number of attendees since it was not part of a structured project and the questionnaires were mainly distributed by the Theatrical company itself. The respondents could rely only on information given them by the show itself, since they could not interact with scientists, making the survey more valuable. Although teen-agers and adults made up for about $29 \%$, the sample, mostly included children in age between 8 and 14 years old and 74\% of them had already felt an earthquake in their lives (Figure 3).

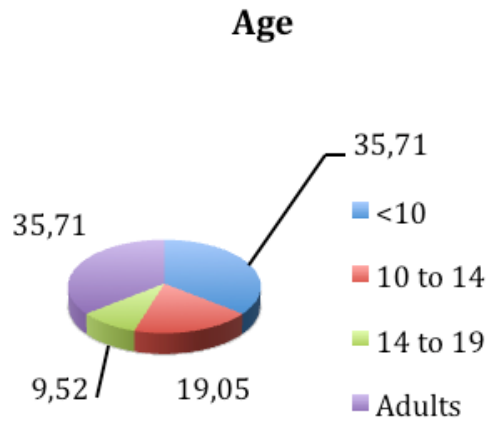

\section{Seismic risk reduction: \\ how?}

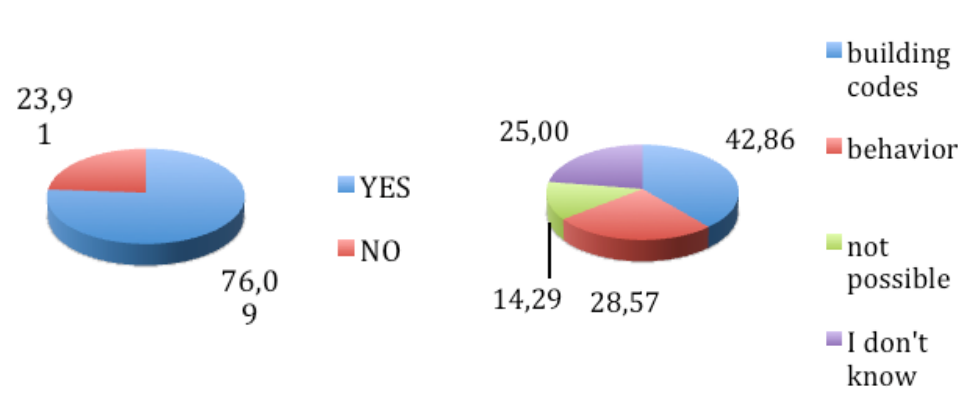

Figure 3. Age distribution of the sample (left); percentage of those who experienced an earthquake during their life (centre); how can we defend ourselves against earthquakes (right) 
Table 2. Emotions driven impact

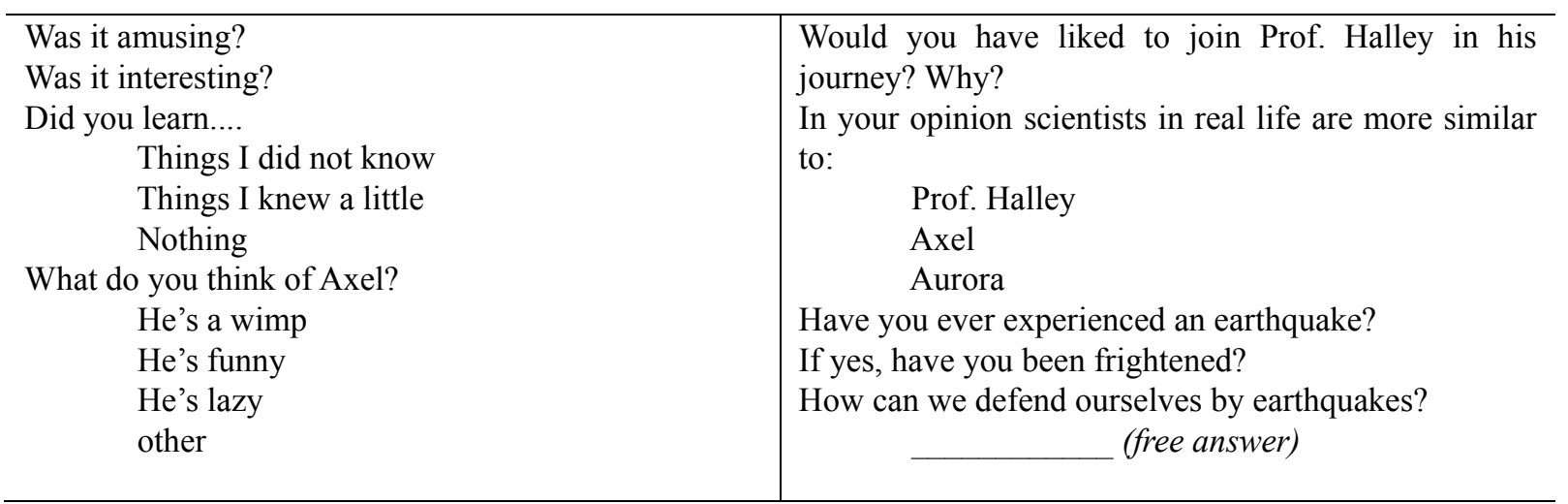

We investigated emotional impact enquiring about enthusiasm, fear, and empathy with the characters and finally about the perception they had concerning what should be done for risk mitigation (Table 2). Since the answer to this last question was let free, we could assess what were the most common ideas on risk mitigation and whether the plot might have affected them. The answers clustered within 4 groups, namely: (i) attaining to building codes; (ii) behaving properly during the shaking; (iii) it is not possible to control nature; (iv) I don't know (Figure 3). Only one of them thought the best would be leaving the area where earthquakes occur. We point out that in the plot Aurora suggest that it does not make any sense to leave a land prone to earthquakes, while the best way to reduce risk is attain to building codes.

We noticed that the amusement and interest on the plot did not depend on age, while, as we expected, $80 \%$ of teen-agers and $87 \%$ of adults answered that they the learned what they barely knew (Figure 4).

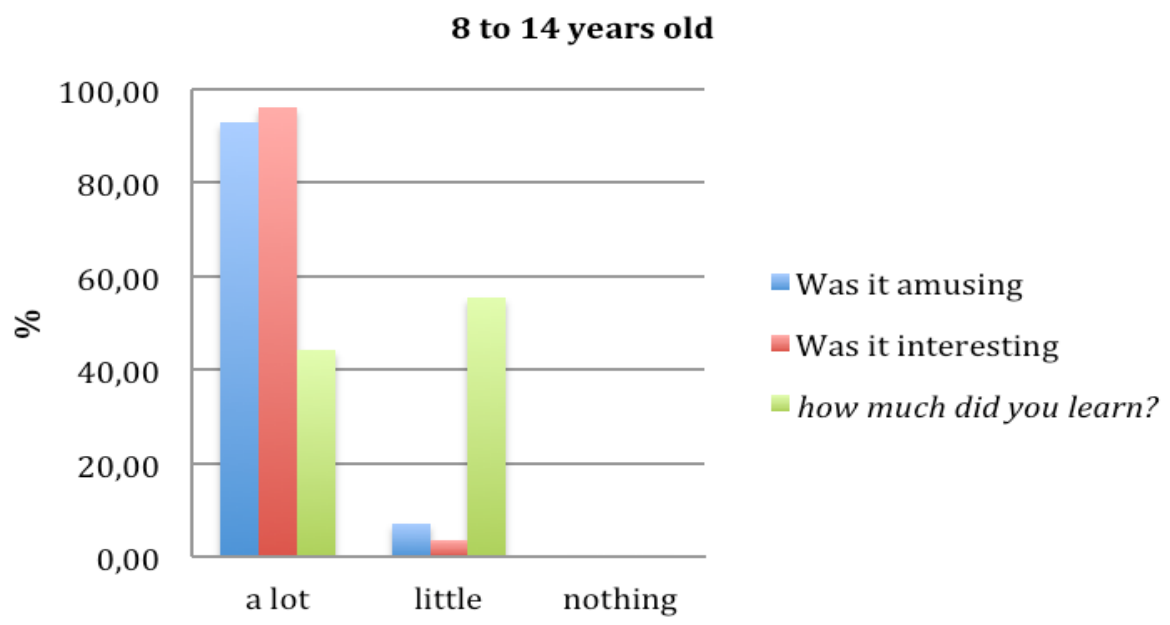

Figure 4. Children 8-14 years old rate the appreciation of the performance. For the question How much did you learn? label "a lot" refers to the answer "things I did not know", label "a little" refers to the answer "things I knew a little" as reported in Table 2

Most of the answers pointed out that scientists are perceived as Aurora (Figure 5), since she seems to know a lot being a good balance between the reflective thinking and the push to explore the unknown. However the percentage of those identifying in Aurora the scientist stereotype decrease with age and adults highlights the need of exploration and experimentation.

A high percentage are prone to follow Halley in his journey specifying that they are curious and adventurous (Figure 5). Interestingly, the number of adults that would not have followed Halley in his journey is twice the children corroborating the idea that as the age increases we are less emotion-driven and more focussed on 
cognitive aspects. They stated that such a journey may never be possible.

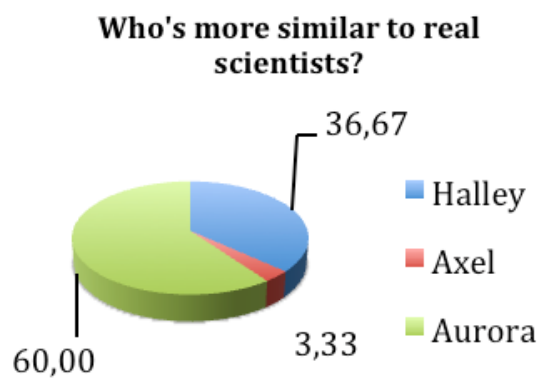

\section{Would you have followed Halley in his journey?}

13,33

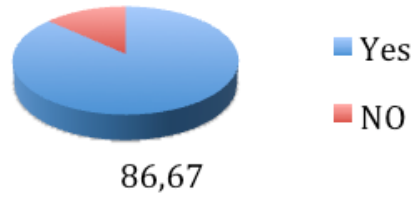

Figure 5. Enquiring about the role of scientists

Since we noticed that adults were more centred on the cognitive aspect of learning, wondering if the plot might be too dense with concepts and the language difficult to understand for children we investigated to which extent the audience captured how the Earth evolved driven by its inner forces (Table 3).

Table 3. Enquiring about cognitive learning

$$
\text { Enquiring cognitive learning }
$$

Do you think one might dive inside the Earth from a Volcano conduit?
No, the lava might come out at any time
90
No, anyway it's too hot

Put a cross in the right answer

Halley found a large underground sea $\quad 10$

Halley found rocks belonging to an ancient ocean $\quad 90$

Halley popped out in the Atlantic Ocean

Write the name of the ancient ocean between Eurasia and Africa?

Tethys

Put a cross in the right answer

Diverging plates give birth to new oceans

Diverging plates give birth to new continents

Converging plates causes continents increase and mountains arise

Which of the following plates gave rise to Alps and Apennines and today still cause volcanic eruptions and earthquakes?

(Mark a cross to the correct sentence)

Europe and Adriatic plates

Eurasian and African plates

northward moving of African plate

What causes an eruption?
lava
magma
gas

When earthquakes occur?

when rocks under stress finally break $\quad 90$

when the Plates move

when rocks get pushed or pulled

Why does the ground shake during and earthquake? 
because it is not stable

because it breaks

Where would you expect an earthquake?

where rocks did already break

where rocks are deformed

on faults

When does an earthquake become a disaster?

when humans do not respect the Planet $\quad 80$

$\begin{array}{ll}\text { when earthquakes are strong } & 10\end{array}$

$\begin{array}{ll}\text { when an earthquakes occurs suddenly } & 10\end{array}$

In italics, the answers given spontaneously by children

When the questions were not structured (i.e., let them free) indeed, the public gave similar answers (italics in Table 2), corroborating our main guideline that there is dependence between the message, the audience and the learning approach. The answers to the questionnaires proved that highly concentrated children, following actors in the journey through imagination, had eventually learned the most important information we intended to pass through, as we inferred by the answers to the questionnaire on cognitive learning. We can then assume that catching on imagination is the best way to raise comprehension. As we have stated several times, the plot is fully driven by imagination, as the journey never really takes place. Questionnaires showed that the aurora borealis and the Special Volcano scenes (Figure 6) mostly triggered children's excitement even if attention was hold using just lights and small tools while the actors were playing the most important role. A poor scenery was definitely the right choice.
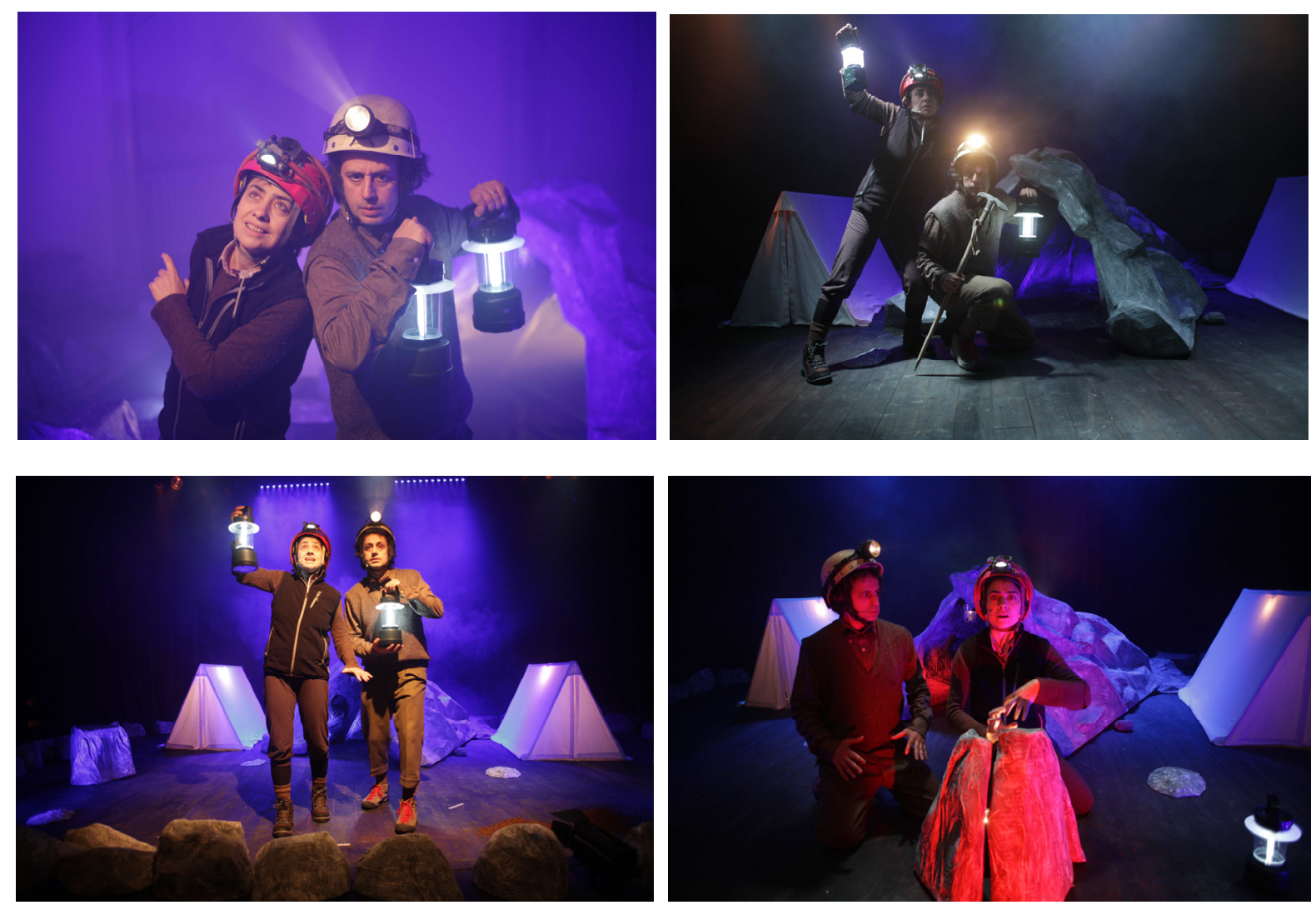

Figure 6. Images from the most appreciated scenes: a, b, c the aurora borealis and the beginning of the journey; $\mathrm{d}$ : the building of the "special volcano" 
An important result of the survey was in contrast with adults' expectations, since a very small percentage of children got frightened by the earthquake rumble while all of them would have been happy to follow Halley in his journey although Axel kept underlining that it was extremely dangerous. When asked which one of the three characters they would expect be the closest to what scientists are in real life, all the children answered Aurora, invoking the fact she seems to know many things. Although all children would have followed Halley in his journey they thought he was not the scientist stereotype they had in their minds. A consequence of the fact science and scientist are still thought to be far away from society? But at list, during the performance, Halley's journey through the Earth was also a trip through knowledge.

\section{Conclusions}

Putting into scene the interior of the Earth was a difficult task to accomplish. We could not rely on special effects to capture the audience attention as at the movies. Addressing mainly to children was a challenge that theatre peculiarities helped to face. Our survey reinforced the idea that science theatre is able to raise children interest about complex issues even if relying on a poor scene, with few actors and maintaining, when it was the case, a technical language. In our case there was very little to watch and too much to imagine. The possibility to make a survey, even if simple and preliminary, can be considered a success in this condition. Indeed, even if by a poor sample, we can infer that children became interested in a topic that is not even contemplated in school curricula and that, under the guidance of our three imaginary scientists, they showed a positive attitude towards natural hazard. After all, even if with an imaginary journey, they had the chance to go inside the Earth where everything originates: the beautiful landscapes and phenomena as a stunning aurora, and the most scaring earthquakes and volcano.

\section{Acknowledgments}

The experience was the result of a joint venture between Istituto Nazionale di Geofisica e Vulcanologia (INGV) scientists and the acting company Teatro del Sole. The director, Antonio Rota is the author of the plot, Marco Prandoni and Francesco Collinelli designed the set. It was supported and promoted by the Science Outreach Laboratory of INGV. We acknowledge the financial support by Campo dei Fiori Regional Park (www.parcocampodeifiori.it) and by Softechweb (www.softechweb.it). We are also grateful to our colleague Giuliana Rubbia for interesting suggestions.

\section{References}

Armelle, A., Marazzi, F., \& Tirelli, D. (2010). Introducing students to structural dynamics and earthquake engineering. Physics Education, 76-82. http://dx.doi.org/10.1088/0031-9120/45/1/009

Bernhardsdóttir, A. E., Thorvaldsdóttir, S., Sigbjörnsson, R., Musacchio, G., Nave, R., Falsaperla, S., ... Jimenez, M. J. (2012). Disaster prevention strategies based on an education information system. 15WCEE, Lisbona, Portugal. Retrieved from http://hdl.handle.net/2122/8148

Bernharðsdóttir, A. E., Musacchio, G., Ferreira, M. A., \& Falsaperla, S. (2015). Informal Education for Disaster Risk Reduction. Bulletin of Earthquake Engineering. http://dx.doi.org/10.1007/s10518-015-9771-9

Carpineti, M., Ghioldi, S., Giliberti, M., Ludwig, N., \& Rota, A. (2005). Facciamo luce sulla materia-lo spettacolo della fisica. Ed: S.I.A.E., Rome (Italy).

Carpineti, M., Ghioldi, S., Ludwig, N., Giliberti, M., \& Rota, A. (2007). TRACCE-Lo spettacolo della Fisica. Ed: S.I.A.E., Rome (Italy).

Carpineti, M., Cavallini, G., Giliberti, M., Ludwig, N., Mazza, C., \& Perini, L. (2006). "Let's throw light on matter": A physics show for primary school. Il Nuovo Cimento, 121B(8), 901-911.

Carpineti, M., Cavinato, M., Giliberti, M., Ludwig, N., \& Perini, L. (2011). Theatre to motivate the study of physics. Journal of Science Communication, 10(1).

D'Addezio, G., Rubbia, G., \& Marsili, A. (2014). The experience of ScienzAperta, a week of scientific information and dissemination. In G. Lollino et al. (Eds.), Engineering Geology for Society and Territory (Vol. 7). Springer International Publishing Switzerland.

Davis, G. A. (1975). In frumious pursuit of the creative person. Journal of Creative Behaviour, 9, 75-87. http://dx.doi.org/10.1002/j.2162-6057.1975.tb00561.x

DeMetz, K. (2007). Toward a Synthesis of Science and Theatre Arts. Forum on Public Policy Online, 11-13.

Fusion Science Theatre. (2012). Retrieved July 2013, from http://www.fusionsciencetheater.org 
Hodder, P. (2011). Science as theatre: A New Zealand history of performances and exhibitions. Journal of Science Communication, 10(2), 1-10.

Hunstad, I., Marsili, A., Casale, P., Vallocchia, M., \& Burrato, P. (2013). Seismic Waves and Sound Waves: From Earthquakes to Music. EduQuakes. http://dx.doi.org/10.1785/0220120095

King, C. J. H. (2010). An analysis of misconceptions in science textbooks: Earth Science in England and Wales. International Journal of Science Education, 32, 565-601. http://dx.doi.org/10.1080/09500690902721681

Komac, B., Zorn, M., \& Ciglič, R. (2013). European education on natural disasters-A textbook study. Nat Hazards Earth Syst Sci Discuss, 1, 2255-2279. http://dx.doi.org/10.5194/nhessd-1-2255-2013

Lanza, T., Crescimbene, M., La Longa, F., \& D’Addezio, G. (2013). Bringing Earth Into the Scene of a Primary School: A Science Theatre Experience. Science Communication, 36(I), 131-139. http://dx.doi.org/10.1177/1075547012473841

Lepper, M. R., \& Cordova, D. I. (1992). A desire to be taught: Instructional consequences of intrinsic motivation. Motivation and Emotion, 16(3), 187-208. http://dx.doi.org/10.1007/BF00991651

Musacchio, G., Maistrello, M., \& Piccarreda, D. (2012). Ricercatori in aula: Esperienze di divulgazione delle Scienze della Terra. Quaderni di Geofisica, 101. http://dx.doi.org/10.1007/s10518-015-9779-1

Musacchio, G., Falsaperla, S., Bernharðsdóttir, A. E., Ferreira, M. A., Sousa, M. L., Carvalho, A., \& Zonno, G. (2015). Education: Can a bottom-up strategy help for earthquake disaster prevention? Bulletin of Earthquake Engineering.

Musacchio, G., Piangiamore, G. L., D’addezio, G., Solarino, S., \& Eva, E. (2015). "Scientist as a game": Learning geoscience via competitive activities. Annals of Geophysics.

Piangiamore, G. L., Musacchio, G., \& Pino, N. A. (2015). Natural hazards revealed to children: The other side of prevention. In S. Peppoloni, \& G. D. Capua (Eds), Geoethics: The Role and Responsibility of Geoscientists. Geological Society (p. 419). London, Special Publications. http://dx.doi.org/ 10.1144/SP419.12

Rota, A. R. (2012). il Cielo si fece Rosso-Viaggio al Centro della Terra. Ed: S.I.A.E., Rome (Italy).

Rule, A. C. (2005). Creativity Skills Applied to Earth Science Education: Examples from K-12 Teachers in a Graduate Creativity Class. Journal of Geoscience Education, 53(1), 53-64.

Science Theatre. (1991). Science theatre at Michigan State University. Retrieved July, 2013 from http://www.pa.msu.edu/sci_theatre/

Taft, R., \& Gilchrist, M. B. (1971). Creative attitudes and creative productivity: A Comparison of two aspects of creativity among students. Journal of Educational Psychology, 61, 136-143. http://dx.doi.org/10.1037/h0028907

Tanner, T. (2010). Shifting the Narrative: Child-led Responses to Climate Change and Disasters in El Salvador and the Philippines. 24, 339-351. http://dx.doi.org/10.1111/j.1099-0860.2010.00316.x

TheatreScience. (2002). Illuminating science and inspiring new theatre. Retrieved July 2013, from http://www.theatrescience.org.uk/ee/ (July 2013)

\section{Copyrights}

Copyright for this article is retained by the author(s), with first publication rights granted to the journal.

This is an open-access article distributed under the terms and conditions of the Creative Commons Attribution license (http://creativecommons.org/licenses/by/3.0/). 